\begin{tabular}{|l|l|l|l|l|l|}
\hline J. Tek. Ling & Vol. 12 & No. 3 & Hal. 309 - 318 & Jakarta, September 2011 & ISSN 1441-318X \\
\hline
\end{tabular}

\title{
ANALISA KEBIJAKAN PENATAAN RUANG UNTUK KAWASAN RAWAN TSUNAMI DI WILAYAH PESISIR
}

\author{
CB Herman Edyanto \\ Peneliti di Pusat Teknologi \\ Pengelolaan Sumberdaya Lahan Wilayah dan Mitigasi Bencana \\ Deputi Bidang Pengembangan Kekayaan Alam
}

\begin{abstract}
Abstrak
Penanganan pengaruh bahaya tsunami bagi masyarakat pedesaan pesisir sangat penting, dengan bertujuan untuk mengurangi atau meminimalkan dampak kerugian atau kerusakan yang disebabkan oleh musbah tsunami tersebut. Namun, efek bencana alam tersebut mungkin tidak terlalu sering dianalisis dan dipertimbangkan dalam beberapa proyek perencanaan tata ruang di Indonesia. Hal ini disebabkan oleh kurangnya informasi dan data mengenai lokasi tersebut. Wilayah pesisir perlu dilindungi dari dampak tsunami dengan mempertimbangkan sejumlah besar orang tinggal di sana dan kegiatan mereka. Adanya pembangunan dari program hutan mangrove oleh pemerintah yang lokal dan peningkatan perencanaan pesisir spasial akan membantu untuk meminimalkan bahaya seperti di pantai.
\end{abstract}

kata kunci: hutan mangrove, perencanaan tata ruang, mitigasi bencana, tsunami.

\begin{abstract}
Handling for the affects of tsunami hazard for the coastal rural people is very important to be taken into action, which aim to reduce or minimize the impact of loss or damage that could be caused by it. However, natural disaster effects might not be too often analized and considered in some spatial planning projects in Indonesia. It is caused by the lack of information and data concerning with the location of study. Coastal areas need to be protected from the tsunami's impact by considering the large number of people who live there and their activities. Thank to the growing of mangrove forest programme by the local governement and the improvement of its coastal spatial planning which help to minimize such hazard in the coast.
\end{abstract}

keywords: Mangrove forest, spatial planning, hazard mitigation, tsunami.

\section{PENDAHULUAN}

\subsection{Latar Belakang}

Proses perencanaan fisik perkotaan dan wilayah di Indonesia, belum sepenuhnya bertitik tolak dari kerawanan bencana alam. Hampir seluruh perencanaan fisik perkotaan dan wilayah di Indonesia sebelum tahun 2000 belum mempertimbangan aspek kebencanaan dan lingkungan sebagai unsur yang penting untuk diikutsertakan dalam perencanaan fisik tersebut. Hal ini bukan menjadi kelalaian pada perencana, namun lebih ditekankan pada fakta bahwa informasi yang selayaknya diberikan oleh disiplin lain yaitu geologi dan lingkungan belum tersedia ataupun belum lengkap, sehingga sisi ini menjadi bagian kelemahan dari sebuah perencanaan fisik. Pengidentifikasian 
masalah kebencanaan dan lingkungan kini menjadi hal sangat penting dan keharusan dalam kegiatan perencanaan. Tsunami merupakan salah satu bencana alam yang dapat terjadi dimana saja disepanjang daerah pantai. Dalam makalah ini tidak ditinjau secara spesifik lokasi sebagai kasus, namun lebih bersifat umum oleh karena keluaran dari kegiatan ini merupakan konsep dalam penataan ruang kawasan pemukiman di wilayah pesisir. Pembahasan mengenai gambaran dan sifat dari bencana tsunami, merupakan hal yang penting untuk diketahui, sehingga upaya untuk pengurangan (mitigasi) kebencanaan dapat dilakukan

Indonesia merupakan salah satu negara yang sangat rawan bencana di dunia. Kejadian berbagai bencana yang melanda di wilayah nusantara ini berlangsung secara terus menerus, baik yang disebabkan oleh faktor alam (gempa bumi, tsunami, banjir, letusan gunung api, tanah longsor, angin ribut, kekeringan), maupun oleh faktor non alam seperti berbagai akibat kegagalan teknologi dan ulah manusia. Pada umumnya bencana yang terjadi tersebut mengakibatkan penderitaan bagi masyarakat, baik berupa korban jiwa manusia, kerugian harta benda, maupun kerusakan lingkungan serta musnahnya hasil-hasil pembangunan yang telah dicapai ${ }^{1}$. Terdapat dua kelompok utama potensi bahaya, yaitu potensi bahaya utama (main hazard) dan potensi bahaya ikutan (collateral hazard). Potensi bahaya utama (main hazard potency) ini diperlihatkan antara lain dengan peta yang menunjukkan bahwa Indonesia merupakan bagian wilayah yang memiliki zona-zona rawan gempa, peta potensi bencana tanah longsor, peta potensi bencana letusan gunung api, peta potensi bencana tsunami, peta potensi bencana banjir, peta kekeringan. Dari indikatorindikator diatas dapat disimpulkan bahwa Indonesia memiliki potensi bahaya utama yang tinggi.

Upaya mitigasi dilakukan sebagai usaha untuk memperkecil, dan mengurangi dampak yang di akibatkan oleh bencana dan pada prinsipnya harus dilakukan untuk segala jenis bencana, baik yang termasuk ke dalam bencana alam (natural disaster) maupun bencana sebagai akibat dari perbuatan manusia(man-made disaster).

Kejadian alam dan bencana yang terjadi banyak yang disebabkan oleh kesalahan manusia dalam penggunaan sumber daya dan tindakan yang tidak memadai serta kurangnya pandangan jauh ke depan. Oleh karena itu perlu pertimbangan yang bijaksana di dalam pengambilan keputusan yang akan dibuat. Mengingat bahwa mitigasi ditujukan untuk mengurangi atau menghilangkan resiko akibat bencana terhadap manusia dan harta bendanya, maka prioritas perlu diberikan untuk kawasan-kawasan strategis yang berpotensi memiliki resiko yang tinggi jika terjadi bencana sebagai akibat akumulasi dari tingkat kerentanan (vulnerability level), yang biasanya memiliki bahaya yang relatif lebih tinggi bila dibandingkan dengan wilayah yang secara umum kurang terbangun, dengan potensi bahaya (hazard potency) yang dimilikinya.

Masalah kerentanan terhadap bencana ini haruslah menjadi fokus utama pemerintah, untuk mengubah keadaan bencana gempa dan tsunami dari situasi kerentanan tinggi ke kapasitas rendah. Penting kita melakukan penilaian dan mengolaborasi kemampuan lokal sebagai dasar utama dari aktivitas pengelolaan bencana.

Selama ini, masalah bencana belum ditangani secara menyeluruh. Hal ini disebabkan beberapa hal, di antaranya tidak adanya kebijakan pemerintah yang integral sehingga bencana ditangani secara parsial, bahkan antar departemen sering tidak terjalin koordinasi. Lebih parah lagi, bencana hanya ditangani dengan pendekatan tanggap darurat. Pasca bencana, rakyat dibiarkan dengan penderitaan yang menimpanya ${ }^{2)}$.

Sebagai bagian dari tindakan aksi, maka pengertian mitigasi dapat dikelompokkan ke 
dalam mitigasi struktural dan mitigasi non struktural ${ }^{2}$. Mitigasi struktural berhubungan dengan usaha-usaha pembangunan konstruksi fisik, sementara mitigasi non struktural diantaranya mencakup penyusunan rencana tata ruang yang perwujudannya akan membentuk pola tata guna lahan yang disesuaikan dengan kerentanan wilayahnya dan memberlakukan peraturan pembangunan. Dalam kaitan itu pula, kebijakan nasional harus lebih memberikan keleluasaan secara substansial kepada daerah daerah untuk mengembangkan sistem mitigasi bencana yang dianggap paling tepat dan sesuai untuk daerahnya. Mitigasi non struktural merupakan upaya untuk melindungi bagian dari lingkungan fisik lingkungan perkotaan terhadap bencana yang mungkin disebabkan oleh terjadinya tsunami diwilayah pesisir.

\subsection{Maksud dan Tujuan}

Maksud dan tujuan dari kegiatan ini adalah mengidentifikasikan permasalahan yang menyangkut bencana tsunami diwilayah pesisir serta menyusun analisa kebijakan dan perencanaannya serta upaya untuk mengurangi bahaya yang ditimbulkannya serta langkah yang perlu diambil dalam penanganannya.

\section{METODA PENDEKATAN}

Metoda pendekatan dalam kegiatan ini merupakan metoda analisis kualitatif dan bersifat library research. Dasar pemikiran secara kualitatif dalam kegiatan ini merupakan langkah-langkah untuk mengembangkan "lingkungan perkotaan yang aman" (Safer City Process) ${ }^{3)}$ seperti memperkirakan kemungkinan yang harus dibangun / dikembangkan untuk "keselamat an perkotaan"

Di dalam realita, penanggulangan bencana masih ditekankan pada saat kejadian serta setelah (pasca) kejadian bencana. Sedangkan tahap sebelum (pra) bencana masih sebatas pada tahapan pencegahan (prevention), yaitu dengan menghindari pemanfaatan kawasan yang kritis atau rawan bencana untuk dikembangkan sebagai kawasan budidaya. Kebiijaksanaan dalam bentuk penataan ruang kota yang ada juga belum memadukan berbagai program pembangunan perkotaan yang berwawasan keamanan dan keselamatan warga kota dari bencana yang mungkin terjadi. Selain itu juga disadari bahwa kebijakan nasional penanggulangan bencana yang ada masih mengandung beberapa kelemahan yang cukup esensial, selain dalam hal substansinya yang masih sangat umum, dan belum mengarah kepada fakta bahwa lingkungan perkotaan memilki kondisi yang jauh lebih rentan.

Bila ditilik dari tingkat kemungkinan pelaksanaan dari kebijaksanaan tersebut di dalam tataran praktek sesuai dengan kondisi dan situasi yang ada. Oleh karenanya, sejak diterapkannya UU No. 22 tahun 1999 mengenai otonomi daerah, peran pemerintah pusat di era desentralisasi baru yang lebih terbatas pada penyusunan norma. pedoman, standard, atau aturan kebijakan pokok. Hal tersebut berimplikasi pada tuntutan penyusunan kebijakan nasional mitigasi bencana yang lebih baik, dalam arti kebijakan nasional yang lebih layak secara teknik, ekonomis, secara politis dapat diterima oleh masyarakat, dan secara administratif dapat dilaksanakan dengan mempertimbangkan berbagai aspek seperti otoritas, komitmen, kapasitas, dan prasarana serta sarana pendukung

\section{PEMBAHASAN}

\subsection{Efek Alam Terhadap Terjadinya Bencana Tsunami}

Posisi Indonesia yang terletak pada pertemuan 3 (tiga) lempeng tektonik di dunia yaitu: Lempeng Australia di selatan, Lempeng Euro-Asia di bagian barat dan Lempeng Samudra Pasifik di bagian timur, 
yang dapat menunjang terjadinya sejumlah bencana. Indonesia merupakan salah satu negara yang memiliki tingkat kegempaan yang tinggi di dunia, lebih dari 10 kali lipat tingkat kegempaan di Amerika Serikat ${ }^{4}$.

Berdasarkan posisinya tersebut, maka hampir di seluruh Indonesia kecuali daerah Kalimantan yang relatif stabil, kejadian bencana gempa tektonik akan sangat mungkin terjadi setiap saat dan sangat sukar diperkirakan kapan dan dimana persisnya bencana tersebut akan terjadi.

Gempa-gempa tersebut sebagian berpusat di dasar Samudra Hindia, dan beberapa dapat memicu terjadinya gelombang laut yang besar yang disebut tsunami. Gangguan implusif yang bersifat transien (gelombangnya bersifat sesar) sebagai pembangkit tsunami setidaknya bersumber dari gempa di dasar laut, letusan gunung api di dasar laut, dan longsoran yang terjadi di dasar laut.

\subsection{Kasus Kebencanaan di Kabupaten Banten}

\section{a) Tsunami Di Kawasan Selat Sunda}

Sejak bencana tsunami akibat letusan

Gunung Krakatau 1883, telah puluhan tsunami merusak terjadi di Kepulauan Indonesia. Kegempaan di Selat Sunda dengan skala di atas 2,5 skala Richer pada tahun 1985 terjadi sebanyak 29 kali, tahun 198614 kali, tahun 19878 kali, tahun 1988 13 kali, tahun 198912 kali dan tahun 1990 sebanyak 6 kali. Berdasarkan pencatatan telemetri didapatkan angka sebanyak 2456 kali gempa pada tahun 1994, dan paling kecil sebanyak 1692 kali tahun 1993. Rata-rata kejadian gempa adalah sekitar 2000 kali setiap tahunnya. Dari catatan kejadian gempa bumi yang terjadi dari tahun 1900 sampai tahun 1993, sebagian besar mempunyai magnitude (M) sebesar 4,1 sampai 6,0. Gempa besar lain yang terjadi di kawasan Selat Sunda adalah pada tanggal 27 Pebruari 1903 dengan skala VI MMI di Banten, 12 Mei 1923 dengan skala VII MMI di Banten yang dirasakan di seluruh Jawa, 24
Juni 1949 skala 7 Richer di dekat Krakatau, 9 Juli 1957 skala 6,2 Richer di sebelah barat Selat Sunda serta 16 Desember 1963 skala $\checkmark$ MMI di Labuhan.

Pada tahun 1883 terjadi letusan sangat dahsyat dari Gunung Krakatau yang terletak di kawasan Selat Sunda terjadi letusan sangat besar dan menyebabkan gelombang tsunami sangat dahsyat yang dalam sejarah merupakan bencana tsunami terbesar yang pernah terjadi di Indonesia. Dampak kerusakan yang paling besar terjadi di pantai Jawa dan Sumatra yang terletak di kawasan Selat Sunda. Beberapa pusat permukiman seperti perkampungan penduduk di Teluk Betung hancur dilanda tsunami dengan tinggi gelombang pasang 20 meter dan menghancur kawasan pantai dan Kota Merak dengan tinggi gelombang lebih dari 30 meter. Lebih dari 36.000 orang meninggal dunia akibat peristiwa tersebut.Gelombang pasang ini juga menyapu Teluk Semangko. Gelombang pasang setinggi 13,6 m juga melanda mercusuar Bengkulen. Letusan

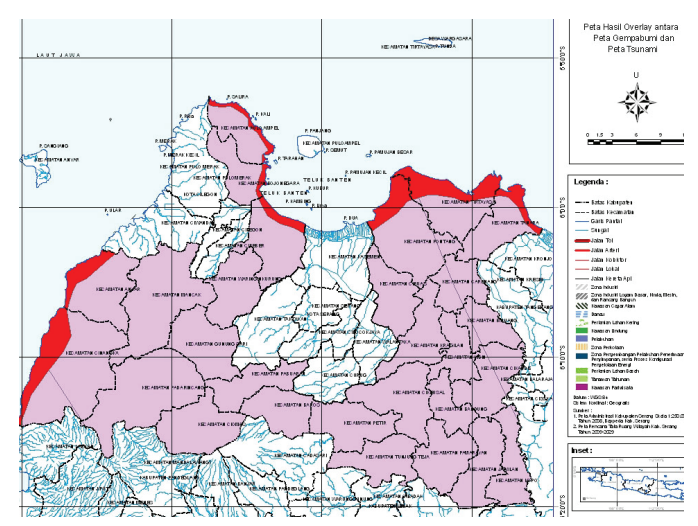

Gambar 1. Peta hasil overlay peta gempa bumi dan peta tsunami di Kabupaten Serang

besar pada Gunungapi tersebut membentuk kaldera serta menyisakan tiga (3) pulau (Rakata, Sertung dan Panjang) yang terletak di pematang kaldera. Sejak tahun 1927 di tengah-tengah kaldera muncul titik letusan baru yang lama-kelamaan menjadi 
kerucut Gunungapi dan dinamakan Gunung Anak Krakatau. Ketiga pulau tersebut adalah sisa pembentukan kaldera, sedang Anak Krakatau tumbuh mulai 20 Januari 1930.. Dari tahun 1930 sampai 1995, Anak Krakatau telah mengerupsi sebanyak 74 kali, baik erupsi eksplosif maupun efusif. Dari sejumlah letusan tersebut, pada umumnya titik letusan selalu berpindahpindah di sekitar tubuh kerucutnya. Erupsi ini merupakan kegiatan rutin Anak Krakatau yang terjadi setiap satu sampai delapan tahun sekali, dan umumnya terjadi empat tahun sekali yang berupa letusan abu atau Ielehan lava. Gelombang tsunami akibat letusan Gunung Krakatau 1883 juga mencapai di pantai Jakarta. Gelombang pasang naik sampai 3 meter dalam beberapa menit, dan menyebabkan banjir dibeberapa tempat di pantai utara Jakarta.

Kemungkinan terjadinya tsunami diperkirakan akan muncul pada kasus erupsi gunung berapi yang berada disekitar kabupaten Serang serta proses dislokasi atau pergerakan lapisan tanah dalam skala yang luas yang mengakibatkan terjadinya tsunami. Para ahli telah mencoba untuk memberikan skenario kemungkinan terjadinya tsunami di wilayah kabupaten Serang sebagaimana diilustrasikan dalam gambar berikut ini5) :

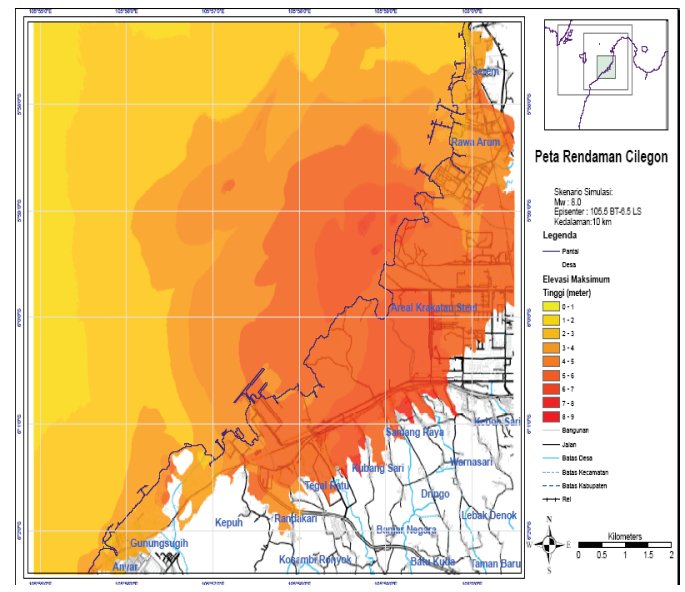

Gambar 2.Peta rendaman Cilegon untuk skenario $\mathrm{Mw}=8.0$

\section{b. Gempabumi}

Berdasarkan kondisi geologis, wilayah Selat Sunda berpotensi dilanda gempabumi, baik gempabumi tektonik, vulkanik maupun longsoran. Akan tetapi bencana gempabumi yang mungkin bersifat merusak dan dominan adalah gempabumi tektonik. Gempa ini dapat terjadi pada bagian lempeng kontinen maupun pada lempeng samudra yang menyusup.

Direktorat Geologi Dan Lingkungan mengidentifikasikan bahwa pada bagian Lempeng Benua Eurasia (overriding plate), khususnya Pulau Sumatera berkembang sesar aktif Semangko yang membujur dari ujung pulau bagian utara ke ujung selatan bahkan menerus ke selatan ujung barat Jawa. Sesar aktif inilah yang berpotensi menjadi sumber gempa dan bila sumber gempanya terjadi pada bagian sesar aktif yang terdapat didaerah perairan (laut) maka akan berpotensi menjadi pemicu terjadinya tsunami. Dilain pihak, pada lempeng samudera Hindia-Australia (subducting plate) disepanjang jalur subduksi yang terdapat dibagian baratnya, mulai dari sekitar palung terus mengikuti kedalaman Zona Benioff juga menjadi tempat sumber gempa dan berpotensi menimbulkan tsunami. Berbicara tentang bahaya tsunami erat sekali dan tidak lepas dari peristiwa gempabumi.

Berdasarkan sejarah kejadian gempa disekitar Selat Sunda, telah terjadi beberapa kali gempa besar. Berdasarkan histori kegempaan tersebut, diketahui bahwa telah terjadi tiga kali gempa kuat (strong / \pm 7 Skala Richter), tepatnya dua kali terjadi disekitar Kota Agung dan sekali di utara Ujung Kulon. Bahkan berdasarkan data dari International Seismological Centre ${ }^{6)}$, gempa tersebut terjadi dalam kurun waktu 1961 sampai 1981. Hal ini menunjukkan bahwa masa perulangan gempa-gempa tersebut tidak begitu lama, khususnya untuk Kota Agung, dimana dalam kurun 20 tahun telah terjadi dua kali gempa besar. Dengan demikian adalah sangat mungkin peristiwa ini akan terjadi lagi di Sekitar Selat Sunda. 
Mengingat hal tersebut, alangkah bijaknya, bila kita melakukan tindakan antisipatif untuk memperkecil terjadinya kerugian, baik harta benda lebih-lebih nyawa bila gempa tersebut terjadi.

Telah dilakukan berbagai penelitian kebumian di Selat Sunda, seperti pengukuran gaya berat, paleomagnetik dan geokimia. Dari penelitan tersebut diketahui bahwa di daerah Selat Sunda terdapat dua struktur graben dan suatu busur seismik dangkal yang berarah utara selatan. Berdasarkan studi paleomagnetik diperkirakan Pulau Sumatera talah mengalami pergeseran memutar searah jarum jam relatif terhadap Pulau Jawa sejak 2 juta tahun yang lalu dengan kecepatan 5-10 / juta tahun dan telah berputar lebih dari $20^{\circ}$. Dengan adanya proses perputaran ini Wilayah Selat Sunda ini telah mengalami pembukaan sejak 2 juta tahun lalu atau sebelumnya (ibid). Dan proses inilah yang mungkin membuka peluang terbentuknya gunungapi (Kompleks Krakatau) yang mampu menghasilkan material piroklastik asam dalam jumlah yang sangat besar. Terdapat beberapa hal penting yang berkaitan dengan potensi terjadinya gempabumi dan intensitasnya, yaitu tingkat keaktifan sesar yang ada, kompleksitas struktur sesar yang ada dan tipe batuan yang akan mempengaruhi lama tidaknya pengumpulan energi dalam tubuh batuannya.

Daerah Selat Sunda disusun oleh batuan-batuan berumur Miosen (sedimen dan volkanik), Pliosen (sedimen dan volkanik), volkanik Pleistosen, Kuarter (tuf dan batuan volkanik lainnya) dan alluvial. Jenis batuan dan soil sangat penting untuk dipetakan secara detail, khususnya tempat dimana bangunan-bangunan berada, karena sifat fisik tanah dan batuan inilah yang berperan dalam menghadapi gangguan baik goncangan gempanya maupun arus gelombang tsunaminya.

Daerah Kota Agung bila dilihat dari kondisi geologisnya sangat berpotensi untuk dilanda bencana gempa bumi dan tsunami.
Ancaman tsunami ini akan muncul dalam tiga bentuk sumber, yaitu tsunami yang ditimbulkan oleh longsoran material bawah laut (mengingat di Selat Sunda berkembang struktur graben / bertebing curam), letusan gunungapi (Anak Krakatau) dan deformasi pada zona subduksi di barat dan baratdaya Sumatera Selatan.

\subsection{Bahaya Bencana Tsunami}

Pengkajian bahaya tsunami dilakukan dengan pemodelan tsunami. Dalam pemodelan numerik tsunami, data-data yang diperlukan adalah data parameter gempa, data batimetri (kedalaman air) dan data topografi. Data parameter gempa seperti kedalaman gempa, panjang dan lebar gempa, sudut-sudut strike, dip, slip dan dislokasi dapat diperoleh dari USGS dan BMG, sedangkan data batimetri dan topografi diperoleh dari Gebco, SRTM yang telah diverifikasi dengan hasil ground check di lapangan.

Data-data yang diperlukan dalam pemodelan numerik ini adalah data parameter gempa, data batimetri (kedalaman air) dan data topografi. Data parameter gempa seperti kedalaman gempa, panjang dan lebar gempa, sudut-sudut strike, dip, slip dan dislokasi dapat diperoleh dari USGS dan BMG, sedangkan data batimetri dan topografi diperoleh dari Gebco, SRTM yang telah diverifikasi dengan hasil ground check di lapangan.

\subsection{Upaya Mitigasi Bencana Tsunami}

Langkah untuk mengurangi dampak dari tsunami dapat dilakukan dalam dalam bentuk $^{7)}$ mitigasi struktur dengan memperkuat bangunan dan infrastruktur yang berpotensi terkena bencana, seperti membuat kode bangunan, desain rekayasa, dan konstruksi untuk menahan serta memperkokoh struktur ataupun membangun struktur bangunan penahan longsor, penahan dinding pantai, dan lain-lain. Selain itu upaya mitigasi juga dapat dilakukan dalam bentuk non struktural, diantaranya seperti menghindari wilayah 
bencana dan konstruksi untuk menahan serta memperkokoh struktur ataupun membangun struktur bangunan penahan longsor, penahan dinding pantai, dan lainlain.

Selain itu upaya mitigasi juga dapat dilakukan dalam bentuk non struktural, diantaranya seperti menghindari wilayah bencana dengan cara membangun menjauhi lokasi bencana yang dapat diketahui melalui perencanaan tata ruang dan wilayah serta dengan memberdayakan masyarakat dan pemerintah daerah.

Kerusakan lingkungan pesisir akibat bencana dapat diminimalisasi dengan berbagai cara. Salah satunya dengan melakukan upaya pengelolaan sumberdaya (ekosistem) yang ada dikawasan pesisir secara baik. Oleh karena itu, perlu dilakukan langkah-langkah yang sistematis dan menyeluruh sebelum dilakukan pengembangan dan pemanfaatannya dalam skala yang lebih luas lagi. Disamping, perlu juga konsep atau model mitigasi lingkungan pesisir yang dapat dijadikan bahan acuan untuk mengatasi degradasi lingkungan pesisir yang terus berlangsung tersebut.

\subsection{Konsep Penataan Ruang Kota Pantai}

Peristiwa bencana tsunami yang dahsyat di Propinsi Aceh khususnya kota Banda Aceh memberikan gambaran akan arti pentingnya penataan ruang kota yang harus mempertimbangkan dampak dari aspek kebencanaan serta posisi geografis dari lempeng bumi, sumber sumber kebencanaan dan keterkaitannya dengan pergerakannya serta kemungkinan dampak yang ditimbulkannya. Dari peristiwa tersebut dapat diukur hingga seberapa jauh aliran air laut masuk kedaratan, ketinggian air, waktu, kecepatan arus dan perilaku air, sehingga dapat diperhitungkan lokasi permukiman yang baru, sistem preventif terhadap besarnya dan kecepatan arus yang menuju kedaratan yang selanjutnya dapat dibangun tanggul penahan gelombang dan upaya penjinakan kekuatan arus yang akan masuk kedalam kawasan perkotaan. Perlindungan terhadap kawasan terbangun (built up area) lingkungan fisik perkotaan perlu memanfaatkan kedua pendekatan mitigasi struktural maupun non struktural. Perlindungan dalam kawasan pembatas kota dan garis pantai akan mempertahankan perlindungan alam dalam bentuk hutan bakau sebagai sabuk hijau alam (green belt) yang akan melindungi hantaman gelombang tsunami ketika mencapai daratan sehingga gerakan air dapat diperlambat karena adanya hutan bakau. Pratikto ${ }^{8)}$, melalui studinya pada 2002, mengatakan, ekosistem mangrove juga dapat menjadi pelindung secara alami dari bahaya tsunami. Hasil penelitian yang dilakukan di Teluk Grajagan, Banyuwangi, Jawa Timur, menunjukkan, dengan adanya ekosistem mangrove telah terjadi reduksi tinggi gelombang sebesar 0,7340 , dan perubahan energi gelombang sebesar $(E)=19635,26$ joule) .

Perlindungan lain di garis pantai adalah pembangunan penahan dinding pantai penahan secara horizontal maupun vertikal yang akan berfungsi sebagai penahan gelombang dan memperlemah daya desak air kearah daratan. Dengan demikian mitigasi struktur dapat pula dilakukan dengan mempertahankan struktur alami seperti tegakan hutan mangrove yang biasanya terdapat dipinggir pantai, yang selanjutnya dilakukan perlakuan khusus pada kawasan yang masuk dalam kategori stabil, yakni pada kawasan yang berada pada stadia 5 ataupun stadia 6 (lihat Gb. 3).

Pembangunan fisik perkotaan perlu untuk ditata kembali dengan mempertimbangkan struktur bangunan, tata letak dan perlindungan terhadap desakan air yang masuk ke dalam kota serta mengurangi sebanyak mungkin jalur jalan yang vertikal terhadap garis pantai serta membangun bangunan secara linier pada jalan yang sejajar dengan garis pantai (lihat Gb 4). Kerusakan akibat tsunami yang dahsyat yang dialami oleh kota Banda Aceh 
pada tahun 2004 adalah kecilnya halangan terobosan air laut yang masuk kedalam kota karena struktur jalan yang vertikal terhadap garis pantai, bahkan sebuah kapal yang beratnya ratusan ton mampu 'mendarat' kedalam kota hingga sejauh $5 \mathrm{~km}$ dari tempat asalnya ditepi laut.

Secara konsepsional penataan ruang kota pantai perlu untuk mempertahankan perlindungan garis pantai dengan bangunan penahan dan pemecah kekuatan gelombang dan kearah darat dibutuhkan zona perlindungan alam dalam bentuk tegakan

hutan bakau. Pembatas antara hutan bakau dan lingkungan fisik perkotaan dapat dibangun tembok pembatas baik yang terbuat dari tembok maupun batu batuan ataupun gundukan tanah dengan ketinggian tertentu yang dibangun memanjang sejajar dengan garis pantai. Di dalam kota perencanaan tata letak diarahkan untuk penataan bangunan dan jalan yang sejajar pula dengan garis pantai dan menyarankan untuk dapat mengembangkan bentuk bangunan dalam bentuk rumah panggung yang memiliki tiang penyangga yang kuat. Satu satunya bangunan yang berdiri ditengah bencana tsunami di Banda Aceh adalah bangunan mesjid yang memiliki tiang penyangga dan dinding yang tidak menutup seluruh bangunan.

Prinsip mitigasi bencana di suatu wilayah mencakup ${ }^{9)}$ :

1. Peningkatan antisipasi kerusakan adalah sebuah bentuk mitigasi yang menunjukkan' peningkatan penanganan' kerusakan sederhana dari sebuah ekosistem. Misalnya, pemugaran sirkulasi air. Lalu, diperbaiki ulang.

2. Meminimumkan (reduksi) dampak adalah sebuah model dari mitigasi untuk mengurangi dampak kegiatan pengerukan dan penambangan pasir demi melindungi habitat pemijahan dan menghindari gangguan terhadap benih dan sumberdaya

3. Kompensasi juga salah satu bentuk dari mitigasi yang berimplikasi pada upaya untuk melindungi agar tidak ada sumberdaya yang hilang. Seperti perlindungan waduk.

4. Replacement sebagai sebuah bentuk melindungi sumberdaya dengan memanfaatkan ruang yang ada kemudian melakukan relokasi keruang lainnya.

\subsubsection{Penataan Ruang Pantai}

Sewajarnya bila semua tata ruang kota di Indonesia juga harus memperhitungkan aspek mitigasi bencana alam gempa dan tsunami kedalam setiap perencanaan fisik perkotaan terutama di kawasan pesisir, sehingga bisa meminimalisasi korban jiwa jika terjadi bencana.Kurangnya informasi, petunjuk (guidance) dalam perencanaan seperti aspek geologi (seperti peta terperinci mengenai patahan, banjir, longsor dsb) mengakibatkan masyarakat telah membangun kembali kotanya tanpa memperhatikan kaidah keamanan dan bencana. Dalam setiap langkah untuk penataan ruang wilayah pantai yaitu dalam perencanaan, pemanfaatan dan pengendalian ruang aspek kemitigasian bencana perlu untuk dipertimbangkan. Dalam perencanaan kawasan pantai pertimbangan untuk perlindungan terhadap sempadan pantai telah ditetapkan melalui penetapan garis sempadan pantai, namun perlindungan terhadap hutan bakau misalnya belum mendapat perhatian terutama ditinjau dari sisi implementasi kegiatan proyek (implementation action) seperti penimbunan pantai (land reclamation) dan pengelolaan untuk perikanan tambak (fishpond culture) . $\mathrm{Hal}$ ini sangat berkaitan dengan perlindungan terhadap lingkungan fisik dan kelangsungan kehidupan mahluk air, sehingga dibutuhkan penilaian ilmiah berdasarkan riset untuk penetapan besaran ruang bagi setiap perencanaan di kawasan pantai.

Pemanfaatan ruang pantai dari daratan hingga laut dalam penting untuk dipertimbangkan terutama bila menyangkut 
kepentingan kehidupan perekonomian masyarakat dan transportasi laut.

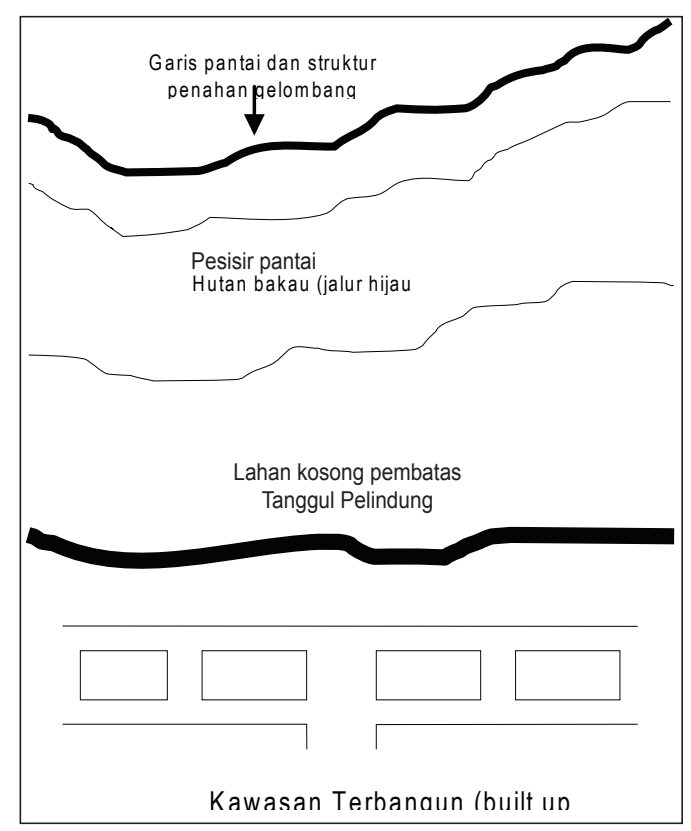

Gambar 3. Konsep Perlindungan Tsunami di Kawasan Pantai

Pembangunan fisik pelabuhan, pembuatan pertambakan, pembangunan bunker perminyakan, jalur transportasi laut, sistem pertahanan militer, aspek kepariwisataan bahari, dsb membutuhkan keterpaduan yang berpijak pada aspek perlindungan lingkungan sehingga perlu untuk ditata dalam koridor penataan ruang. Pengendalian ruang pantai dibutuhkan untuk memberikan batasan sejauhmana pengelolaan pantai telah melampaui batas kemampuannya untuk diberikan beban yang lebih dalam pembangunan fisiknya, sehingga kedepan tidak terjadi pemanfaatan ruang yang tidak terkendali.

\subsubsection{Perlindungan Terhadap Kawasan Pantai}

Manusia merupakan objek bagi perlindungan dikawasan pantai. Dalam banyak kasus perlindungan terhadap keselamatan manusia sering terlupakan dalam perencanaan penataan ruang wilayah, sehingga kejadian tsunami selalu membawa korban jiwa. Wilayah pantai yang memiliki kawasan dataran tinggi, dapat memanfaatkannya sebagai area evakuasi, namun kawasan kepulauan kecil sering tidak memilikinya, sehingga dibutuhkan bangunan buatan manusia (artificial building) untuk perlindungannya. Beberapa bangunan pantai seperti pelabuhan, shelter dsb dapat digunakan untuk tujuan tersebut. Di Jepang di kota Aonae atap pelabuhan perikanannya dibeton dan terbuka serta diberikan tangga sehingga dapat digunakan untuk lokasi evakuasi. Demikian juga bangunan shelter yang ada dibuat bertingkat untuk wadah evakuasi. Namun bila tidak terjadi tsunami, lokasi inti dapat digunakan untuk sekolah dan keperluan warga lokal. Untuk kondisi yang terpencil seperti pulau pulau kecil, bangunan perlindungan tersebut dapat dibuat dari bahan lokal seperti pohon kelapa sebagai pilarnya dengan ketinggian tertentu dengan luas bangunan disesuaikan dengan areal yang tersedia dan berada ditengah tengah atau dekat dengan lingkungan permukiman. Bangunan lain yang dapat didirikan adalah tembok laut dan tanggul pantai. Kota Padang menggunakan tembok pantai sejajar dengan garis pantai dan susunan batuan yang menjorok kelaut sebagai penahan gelombang. Selain itu dapat dilakukan dengan memanfaatkan tripod sebagai pemecah gelombang laut (break water) serta mengurangi tekanan terhadap kawasan pantai serta pintu penahan tsunami dimulut muara sungai. Disamping itu terdapat usaha lain yang bersifat preventif dan non fisik yakni dengan menerapkan zonasi penataan kawasan pantai dan penataan ruang kota/ wilayah yang ramah terhadap bencana tsunami, melakukan relokasi pemukiman dan penanaman bakau serta perlindungan terhadap hutan bakau.

\section{KESIMPULAN DAN SARAN}

- Kota kota pantai membutuhkan 
perlindungan terhadap kemungkinan terjadinya bencana tsunami. Aspek kemitigasian tsunami khususnya perlu untuk dirangkum secara terpadu dalam penyusunan rencana induk kotanya, yang terkait baik dalam proses perencanaan, pemanfaatan dan pengendalian ruangnya, dan disosialisasikan sekaligus menjadi pedoman dalam pelaksanaan pembangunan kotanya.

- Diperlukan perlindungan secara fisik dapat dilakukan dengan merealisasikan bangunan pantai seperti tembok pantai dalam bentuk bentangan tripod dan pemecah gelombang, serta mewujudkan hutan bakau sepanjang pantai.

- Disarankan untuk dapat mengembangkan bentuk bangunan dalam bentuk rumah panggung yang memiliki tiang penyangga yang kuat dipemukiman pantai untuk arena evakuasi

- Membentuk kerjasama antara berbagai pihak, baik dari pemerintah, swasta maupun masyarakat dalam proses penyiapan dan pelaksanaan kegiatan mitigasi bencana tsunami

- Memformulasikan dan mengimplemen tasikan rencana tindak (action plan) kolaborasi antara berbagai pihak. Rencana ini harus disusun berdasarkan prioritas, tujuan, indikator, kerangka waktu dan sistem pemantauan.

\section{DAFTAR PUSTAKA}

1. Bakornas PBP, 2002,Arahan Kebijakan Mitigasi Bencana Perkotaan di Indonesia" Sekretariat Badan Koordinasi Nasional Penanggulangan Bencana Dan Penanganan Pengungsi , Jakarta,

2. Mahfud, 2009.' Harian Pikiran Rakyat, Bandung, Senin 07 September 2009

3. World Habitat Day 2009, Planning Our Urban Future. UN-Habitat

4. Diposaptono, Subandono dan Budiman, 2008. Hidup Akrab Dengan Gempa dan Tsunami, Bogor, Penerbit Buku IImiah Populer.

5. Hamzah Latief DR Meng.' Model RunUp Tsunami Cilegon-Anyer, Banten

6. Rahmat Kurnia, Yonvitner, Seo IL Gyo, Mujijat Kawaroe, Budi Sugianti, Efi Toding Tondok, 2005, Pengelolaan Ekosistem Dan Mitigasi Bencana Di Wilayah Pesisir', Sekolah Pasca Sarjana IPB.

7. Rachmat Agus Dr.Ir. 2005, Manajemen Dan Mitigasi Bencana' Kepala Badan Pengendalian Lingkungan Hidup Daerah (BPLHD) Provinsi Jawa Barat.

8. Pratikto, W, A. 2004. Mitigasi Bencana Tsunami, Artikel Republika, 31 Desember 2004

9. Clarks, J. R. 1996. Coastal Zone Management Handbook. Lewis Publisher. 693 p. 